\title{
Schulz nasz bliźni
}

Gdy w 1947 roku Pierre Klossowski nazwał de Sade’a swoim b l i ź n i m, w istocie przemawiał w imieniu całego pokolenia francuskich intelektualistów, pisarzy i artystów, dla których postać „boskiego markiza” stała się emblematyczna zarówno jako źródło filozoficznej inspiracji, jak i figura egzystencjalna - ucieleśnienie nonkonformizmu, absolutnego buntu przeciwko wszelkim formom zniewolenia myśli (bo przecież „Jakkolwiek ludzie by się tego obawiali, filozofia powinna powiedzieć wszystko"), nawet za cenę pogardy, jaką ukarali go współcześni. Zbiór esejów Sade mon prochain był pierwszym tak systematycznym ujęciem twórczości markiza, ale przede wszystkim zwiastował nowe, nierzadko polemiczne wobec siebie, studia. Wkrótce o autorze 120 dni Sodomy napiszą Bataille, Blanchot, Camus, de Beauvoir, a potem Barthes, Ricoeur, Lacan, Deleuze czy Kristeva (by pozostać wśród Francuzów). Dzisiaj, z oddalenia kilku dziesięcioleci, widać jak na dłoni, że humanistyka XX wieku uczyniła $\mathrm{z}$ jego pisarstwa jeden ze stałych, negatywnych lub afirmatywnych, punktów odniesienia: egzystencjalizm, studia nad erotyzmem i transgresje, panoptyzm, krytyka władzy i historia ciała to zaledwie kilka przykładów tej obecności.

Był zatem Sade bliźnim każdego z nich. Ale przecież nie o takim, zracjonalizowanym i „strukturalnym”, poczuciu pokrewieństwa mówi Klossowski, gdy nazywa autora Julietty s w o i m bliźnim. A przynajmniej nie tylko. Jego deklaracja sięga - jak się wydaje - jednocześnie znacznie głębiej, do czegoś w nim najbardziej intymnego i ciemnego, co rozgrywa się poza rozumem (Schulz określał takie treści „żelaznym kapitałem fantazji”, „,korzeniami indywidualnego ducha”, „mitycznym matecznikiem”). Rozpoznając w Sadzie bezwarunkowego sprzymierzeńca i partnera, który opisał przed nim „te same miejsca”, Klossowski w swoim mniemaniu - przede wszystkim odpowiada na wezwanie, jakby zakodowane w dziele markiza i niedostępne profanom, jak szyfry tajemnego stowarzyszenia (na przykład Stowarzyszenia Miłośników Zbrodni), ukryte między stronami pornograficznej książki, czekające na oświeconego czytelnika.

Bo jest u markiza powracająca figura, pragnienie spotkania doskonałego, porozumienia, które nie potrzebowałoby argumentów i ciężaru słów, spotkania elitarnego, w mgnieniu oka („zwracam się jedynie do tych, którzy mogą mnie zrozumieć”). Pragnienie nieobce także Schulzowi, jeśli zaufać jego korespondencji, choć zarazem tak odmiennie realizowane. Ten pierwszy, który spędził w więzie- 
niach prawie trzydzieści lat, a w swoim epitafium opłakiwał siebie jako „najbardziej nieszczęśliwego z ludzi”, zza murów i kratowanych okien pisał do „wspólników”. Ten drugi też dobrze znał uczucie $\mathrm{z}$ a m u r o w a n i a, mimo że w celi, o ile wiadomo, nigdy nie spędził dnia. Ślad tego doświadczenia samotności zachował się na przykład w słynnym liście do Tadeusza Brezy z 21 czerwca 1934 roku, gdzie Schulz mówi o potrzebie „towarzysza”, o pragnieniu „poręki świata wewnętrznego”, który dopiero „w czterech oczach staje się rzeczywistością”. Chronologiczna lektura Księgi listów pokazuje, jak bardzo dotkliwa i osadzona w codzienności, odczuwana cieleśnie była ta tęsknota Schulza oraz jak silne, na przestrzeni lat coraz trudniejsze, było jego doświadczenie zamknięcia w „szklanym słoju”, w klatce własnego ciała czy wreszcie - w klaustrofobicznych sidłach historii.

$\mathrm{W}$ pismach pierwszego nie ma miejsca na empatię. Zgodnie $\mathrm{z}$ jego filozofią integralnej potworności, jedyne wspólnictwo może się zawiązać pomiędzy „ludźmi suwerennymi", których skłaniają ku sobie kolejne, popełniane apatycznie zbrodnie. W opowiadaniach drugiego - przeciwnie - na współodczuwanie zasługują nie tylko cierpienia ludzi, ale też much, roślin, pałub czy „ukrzyżowanych drzew”. Rację miał Marian Jachimowicz, gdy pisał, że dzieło Schulza „jest szeregiem błyszczących blizn". Bliźni to ten, kto rozpoznaje w sobie ranę innego? Pauza.

Schulz, podobnie jak Sade, doczekał się wielu oddanych komentatorów-bliźnich. Schulzologia narodziła się z takiej właśnie deklaracji Jerzego Ficowskiego („Znalazłem Autentyk”). A po nim byli następni olśnieni i olśnione, uwiedzeni i uwiedzone „do przedsięwzięć odkrywczych”. I są nadal, przecież ciągle ich przybywa. „Kiedy czytam opowiadania Schulza, mam silne poczucie, że nie chcę interpretować, że chcę robić coś innego" - ujawnia się jedna z nich w numerze dwunastym „Schulz/Forum”. Ale autor Sanatorium pod Klepsydra, tak jak „,boski markiz" w XX wieku, staje się dla nas, próbujących odnaleźć się w coraz mniej zrozumiałej i coraz bardziej groteskowej rzeczywistości wieku XXI, także punktem odniesienia, emblematem pewnej konstytucji intelektualno-estetycznej (Józef Olejniczak). Dzisiaj szczególnie mocno odczuwamy niesprawiedliwość i małostkowość ataku Wyki i Napierskiego na apolityczne status quo Schulza (Eliza Kącka). Nagle okazuje się, że to właśnie „antyhumanistyczna” poetyka Schulzowska, a nie - na przykład - „zaangażowane” pisarstwo Hemingwaya, potrafi udźwignąć ciężar postpamięci Holokaustu (Kris van Heuckelom).

Ze swoimi elementami nowego materializmu, nie-atropocentryzmu i etyki troski Schulz jawi się obecnie jako zwiastun nowego paradygmatu w kulturze polskiej, który dokonuje się na naszych oczach. Niewykluczone, że już niebawem ktoś zadekretuje w imieniu całego pokolenia posthumanistów: Schulz nasz bliźni. Czy słusznie? Tymczasem jesteśmy w zawieszeniu, zdani na siebie. $Z$ drżeniem głosu i przeczuciem czegoś intymnego i ciemnego w nas powtarzamy zatem, każdy w swoim imieniu: Schulz mój bliźni. I ja też to powiem.

Schulz mój bliźni. jo 